\title{
DISTRIBUIÇÃO ESPAÇO-TEMPORAL DE FÊMEAS EMBRIONADAS DO CAMARÃO MACROBRACHIUM AMAZONICUM À JUSANTE DA USINA HIDRELÉTRICA DE ÁGUA VERMELHA
}

\author{
Carvalho, A.L.C. ${ }^{1,}$; Rodrigues, L.R. ${ }^{1} ;$ Costa, J.R.P. ${ }^{1}$; Nunes, J.S. ${ }^{1}$; Brito, G.A. ${ }^{1}$; \\ Pantaleão, J.A.F. ${ }^{2} \&$ Andrade, L.S. ${ }^{1}$ \\ ${ }^{1}$ Universidade Federal do Triângulo Mineiro (UFTM), Campus Iturama, Grupo de Ensino, Pesquisa e Extensão em \\ Animais Aquáticos - GEPEAA \\ ${ }^{2}$ Universidade Federal do Triângulo Mineiro (UFTM), Campus Uberaba, GEPEAA \\ *Autor correspondente: analaura.bio@hotmail.com
}

\begin{abstract}
Embora as barragens sejam necessárias para o abastecimento humano e principalmente gerar energia elétrica, essas construções provocam grandes distúrbios nos ambientes aquáticos, muitas vezes irreversíveis. A reprodução das espécies, em tais condições, pode ser modificada de maneira que a população seja reduzida ou até eliminada do ambiente. Nesse sentido, o objetivo desse trabalho foi avaliar as condições reprodutivas do camarão $M$. amazonicum à jusante da Usina Hidrelétrica de Água vermelha situada no Rio grande, divisa entre os estados de são Paulo e Minas Gerais. Os animais foram coletados mensalmente, de Outubro/2017 a Março/2018, em 6 distintos pontos do Rio Grande, sendo o ponto 1 a mil metros e o ponto 6 a 4 mil metros da contenção do fluxo d'água. Uma peneira de saco, própria para camarões, foi arrastada três vezes, em giro de $180^{\circ}$ antes da colocação das armadilhas. Estas últimas foram amarradas à margem do rio e deixadas em espera por aproximadamente 6 horas. Os animais coletados foram individualizados por ponto e mês. Em laboratório, foram sexados e as fêmeas portando ovos foram contabilizadas. Foram coletados 6455 animais, sendo 4793 fêmeas (294 com ovos). A presença de fêmeas portando ovos foi mais evidente nos três pontos mais próximo da barragem, sendo o ponto 2 com o maior número de fêmeas ao longo dos meses (119 fêmeas), diferindo significativamente (Anova, $p<0,04)$ dos pontos 4, 5 e 6 (11, 2 e 7 fêmeas reprodutivas, respectivamente). Durante a avaliação temporal, também foi notada maior abundância dessas fêmeas nos meses de Outubro, Novembro e Dezembro. No entanto, foi observada diferença significativa (Anova, $p<0,05$ ) apenas entre os meses de Novembro (99 fêmeas reprodutivas) com os meses do ano 2018 (20, 24 e 40 fêmeas com ovos, respectivamente). Tais resultados facilitam o entendimento da variabilidade das populações em ambientes diferentes, sugerindo buscas de maiores informações sobre hábitos e características dos ciclos de vida da espécie, bem como sustentará informações para elaboração de planos de manejos eficazes que visam proteger as espécies naturais.
\end{abstract}

Palavras-chave: reprodução, camarão fantasma, Caridea, ovígeras. 